\title{
CHARACTERISTICS OF TEENAGERS' GAIT AND FOOT PRESSURE DISTRIBUTION IN MID-LONG DISTANCE RUNNING
}

\author{
Yimeng FAN ${ }^{1}$, Caixia FU ${ }^{2}$, Lili ZHAO ${ }^{1 * *}$, Lijing FAN ${ }^{3}$, Qidong HUANG ${ }^{4}$ \\ ${ }^{1}$ Department of Sports Work, Hebei Agricultural University, Baoding 071000, China \\ ${ }^{2}$ Department of State Assets Management, Hebei Agricultural University, Baoding 071000, China \\ ${ }^{3}$ Department of Mechanical and Electrical Engineering, Hebei Agricultural University, Baoding 071000, China \\ ${ }^{4}$ Suihua University, Suihua 152061, China
}

\section{CHARACTERISTICS OF TEENAGERS' GAIT AND FOOT PRESSURE DISTRIBUTION IN MID-LONG DISTANCE RUNNING}

ABSTRACT. By using Rs-scan insole pressure test system, this article measures and analyses teenagers' gait and foot pressure in mid-long distance running and conducts quantitative experiment to mid-long distance running by selecting master, level $1 \& 2$ teenage runners to form the experiment group and ordinary university students to form the control group. Firstly, it briefly introduces the development of research on running gait biology and foot pressure test system. By dividing feet pressure into various areas and using effective experimental method, it designs and measures such parameters as gait cycle \& phase, Center of Pressure (COP) track, Pressure-Time Integral (PTI), Partition Peak Pressure (PP), etc. Finally, it reaches relevant conclusions through comparative analysis of measurement data. This research provides theoretic support and data basis for research on foot pressure distribution, mechanism of force in different phases of sport and prevention of sports injury.

KEY WORDS: mid-long distance running, rs-scan, gait, foot pressure distribution characteristics, contrast experiment

\section{CARACTERISTICILE MERSULUI ȘI ALE DISTRIBUȚIEI PRESIUNII PLANTARE LA ADOLESCENȚI ÎN TIMPUL ALERGĂRII PE DISTANȚĂ MEDIE ȘI LUNGĂ}

REZUMAT. Acest articol măsoară și analizează mersul şi presiunea piciorului la adolescenți în timpul alergării pe distanță medie și lungă utilizând sistemul de testare a presiunii branțului Rs-scan și efectuând un experiment cantitativ de alergare pe distanță medie și lungă prin selectarea unor adolescenți la nivel 1, 2 și expert, care au format grupul de experiment și a unor studenți obișnuiți pentru a forma grupul martor. În primul rând, se prezintă pe scurt evoluția cercetărilor privind biomecanica alergării și sistemul de testare a presiunii piciorului. Prin împărțirea piciorului în diferite zone de presiune și prin utilizarea unei metode experimentale eficiente, se proiectează și măsoară parametri cum ar fi ciclul și faza de mers, traiectoria centrului de presiune (COP), integrala presiune-timp (PTI), presiunea maximă pe zone (PP) etc. În cele din urmă, se ajunge la concluzii relevante prin analiza comparativă a datelor măsurate. Această cercetare oferă sprijin teoretic și o bază de date pentru cercetarea privind distribuția presiunii piciorului, mecanismul forței în diferite faze ale sportului și prevenirea rănilor sportive. CUVINTE CHEIE: alergare pe distanță medie şi lungă, Rs-scan, mers, caracteristici de distribuție a presiunii piciorului, experiment de contrast

\section{LES CARACTÉRISTIQUES DE LA MARCHE ET DE LA DISTRIBUTION DE LA PRESSION PLANTAIRE CHEZ LES ADOLESCENTS PENDANT LA} COURSE DE MOYENNE ET LONGUE DISTANCE

RÉSUMÉ. Dans cet article on mesure et on analyse la marche et la pression du pied chez les adolescents pendant la course de moyenne et longue distance en utilisant le système de test de la pression Rs-scan et on réalise une expérience quantitative de la course de moyenne et longue distance en sélectionnant des coureurs adolescents au niveau 1, 2 et expert, qui ont formé le groupe d'expérimentation et quelques étudiants réguliers pour former le groupe témoin. Tout d'abord, on présente brièvement l'évolution de la recherche sur la biomécanique de la course et le système de test de la pression du pied. En divisant les pieds dans de différentes zones de pression et par l'utilisation d'une méthode d'expérimentation efficace, on a conçu et mesuré des paramètres tels que le cycle et la phase de la marche, la trajectoire du centre de pression (COP), l'intégrale pression-temps (PTI), la pression maximale dans les zones (PP), etc. Enfin, des conclusions pertinentes sont obtenues par l'analyse comparative des données mesurées. Cette recherche fournit un soutien théorique et une base de données pour la recherche sur la distribution de la pression du pied, le mécanisme de la force dans diverses phases du sport et la prévention des blessures sportives.

MOTS CLÉS: course de moyenne et longue distance, Rs-scan, marche, caractéristiques de distribution de la pression du pied, expérience de contraste

\footnotetext{
* Correspondence to: L.L. ZHAO, Hebei Agricultural University, Baoding 071000, China, email: 31883920@qq.com
} 


\section{INTRODUCTION}

Running is the most common sport and the major event of athletics. It plays an important role in such big sport events as the Olympics [1]. As exercises have become more and more popular in China and people have increased their exercise awareness, increasingly more adolescents have chosen mid-long distance running to do fitness. Meanwhile, athletes are eager to improve their competition results in this sport. Therefore, in order to do the exercise of mid-long distance running scientifically and reduce sports injury, it is of significance to study the biomechanical characteristics of adolescents in mid-long distance running so as to obtain quantitative experimental data and qualitative theoretic analysis [2].

In recent years, it has been a hot field to study biomechanics of the foot movement, and running has received more and more attention as a branch of foot mechanics, which has been extensively studied in such applications fields as sports, medical care and engineering [3]. However, stating late, the study of running has been in lack of systematic research on different types of running including mid-long distance running.

Research on foot gait and stress distribution during mid-long distance running is of guiding significance not only to doing sports scientifically, but also to designing running shoes, thus having economic benefits [4]. Therefore, this article studies the foot biomechanical characteristics of adolescents in mid-long running. It selects three grades (master, level 1\&2) of mid-long distance runners as subjects, and ordinary college students to form the control group, thus making the experiment measuring data more contrastive and meeting the requirements of guiding different groups [5]. It briefly introduces biomechanics of running gait and compares the functions of different foot pressure test systems as well as their application in foot pressure study. Rs-scan insole pressure test system was finally chosen to record and measure people's gait character and foot pressure distribution in different phases of mid-long distance running [6]. On one hand, the study will help athletes to seek for more scientific methods in mid-long distance running. On the other hand, it will help ordinary enthusiasts to refer to foot characteristic of athletes and keep correct running posture, thus protecting their feet. In addition, the study will be of guiding significance to improve technical level and self-innovation capability of China's sports shoes manufacturing industry.

\section{BACKGROUND OF THE STUDY}

\section{Study on Biomechanical Characteristics of the Running Gait}

Individualized study of running started in the $20^{\text {th }}$ century. At the beginning it mainly centered on study of full-speed and short running while distance running and endurance run did not obtain enough attention. After "the fever of run" emerged, middle-distance running was gradually studied further. Development of biomechanical study on running can be divided into 3 phases: enlightenment period, foundation period, and development period [7].

After Newton found the Three Laws of Motion in the $17^{\text {th }}$ century, relevant scholars laid the foundation of Exercise Physiology on the basis of them. That was the enlightenment period. During the foundation period, the foundation of inverted pendulum model assumption laid the theoretic frame of Gait Biomechanics [8]. Successively invention of velocimeter, accelerometer, force platform, photographic and mathematical method of gait study initiated a new direction in the fields of sports research. In development period, fast expansion of computer technology spawned numeric simulation algorithm and sensor pressure-sensing test equipments, thus improving preciseness and depth of research field [9].

\section{Running Sports Research Problems and Re- search Prospects}

The gait biomechanics run as an important branch of sports biomechanics, contains rich content and valuable research results and has formed a complete theoretical framework and knowledge system. It has important guidance in 
sports, medical and engineering fields. Domestic research in this field started late. The current research focused on clinical rehabilitation. The research results were also fragmented and not systematic. The lack of basic theories severely restricted the improvement of research in the application field. At present, researches on sporting events such as walking, long jump/ triple jump, pole vault, hurdles, etc. are mostly focused on kinematics. The analysis of mechanics is rarely reported, and no foot three-dimensional force and pressure distribution feature models of the above sports items have been found [10].

With the maturation of plantar pressure measurement techniques, it has expanded new application prospects and research areas in clinical biomechanics, human ergonomics and sports biomechanics and other areas. The data of plantar pressure measurement will provide new methods and technologies for dynamic measurement and evaluation of various types of walking, running, casting, balancing movements, supporting movements, take-off and landing movements. Combined with foot scanning technology, it is expected to provide a reliable basis for the design of sports shoes for different projects and the design of individual sports shoes for elite athletes.

\section{STUDY METHOD}

\section{Object of Study}

14 elite mid-long distance runners were selected as subjects of test group. Among them, there were 4 male athletes with an average height of $174 \mathrm{~cm}$, the average exercise age was 4.75 years and the average weight was 61.5 $\mathrm{kg}$. Meanwhile, 10 were female athletes and the average height was $167.7 \mathrm{~cm}$, the average exercise age was 5.4 years and the average weight was $49.8 \mathrm{~kg}$.

8 ordinary college students were selected to form the control group. Eight ordinary universities were selected as the control group for this study. Among them, there were 3 males with an average height of $171 \mathrm{~cm}$ and an average weight of $67.3 \mathrm{~kg}$. Meanwhile, 5 female athletes had an average height of $168 \mathrm{~cm}$ and an average weight of $53.4 \mathrm{~kg}$. No exercise age was found in the control group.

\section{Instruments and Facilities}

1. Rs-scan insole force system, 400 sensors on each foot, sensor volume $0.5 \mathrm{~cm} * 1 \mathrm{~cm}$, sampling frequency $500 \mathrm{~Hz}$, sampling time $8 \mathrm{~ms}$.

2. Laser Doppler Anemometer (LDV) and camera.

\section{Testing Method and Steps}

Testees need to finish mid-long distance running of $10000 \mathrm{~m}$ within 30 minutes wearing Rs-scan insoles and uniform sports shoes. Before test instructions and objectives were explained to them. Data were recorded during test and saved for analysis.

Test steps were as below: register testee's information - do preparation, warm-up and give instructions - install test instruments - pretest - test - read and save data - remove instruments and check insole conditions. Test instruments were installed and connected as shown in Figure 1. 


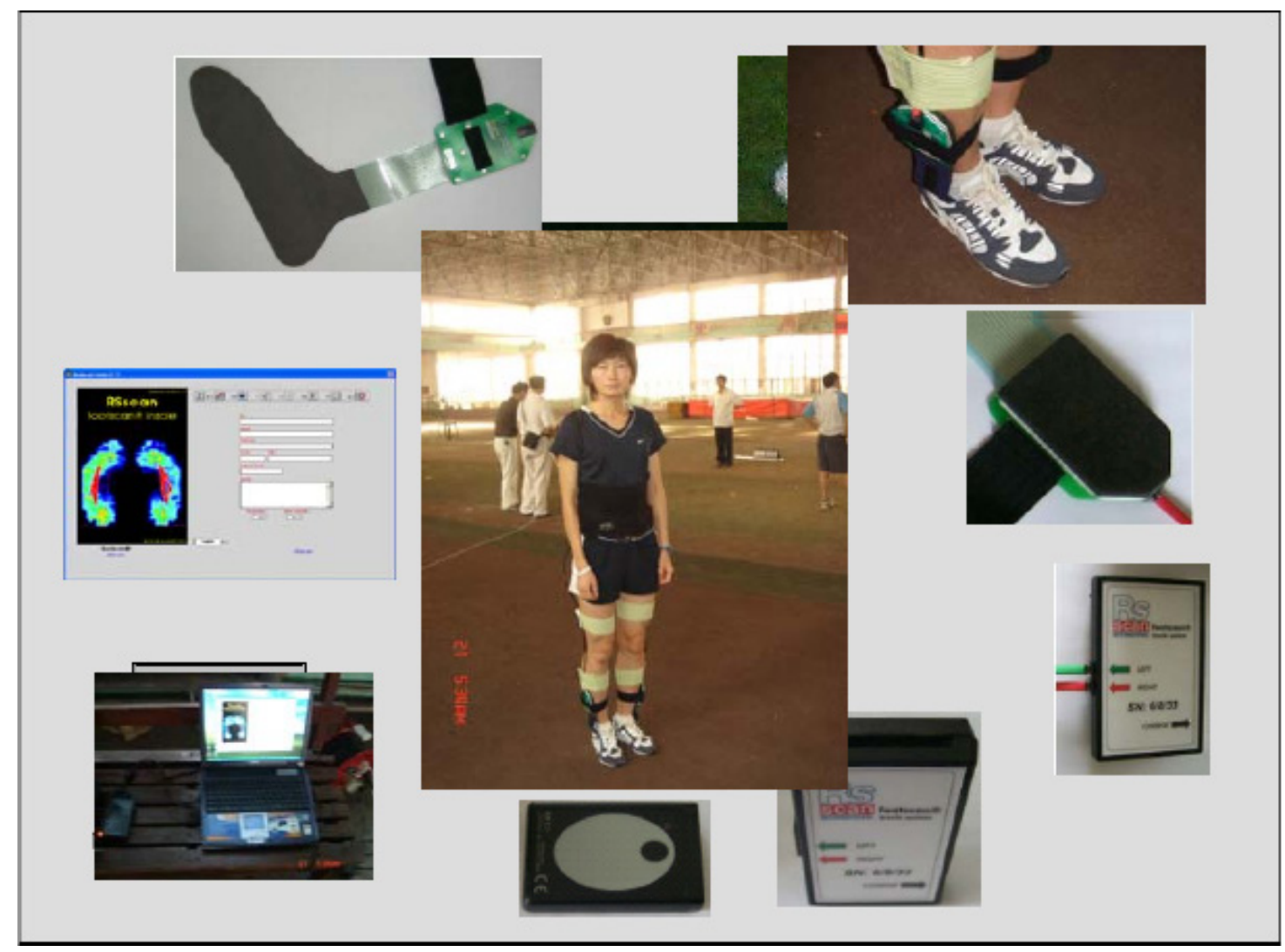

Figure 1. The test instrument installation and connection diagram

\section{Foot Pressure Test Area}

The plantar can be divided into 10 test partitions, T1, T2-T5, M1-M5, MF, HM. Toe 1 indicates the thumb, Toe2-Toe5 represents the $2^{\text {nd }}-5^{\text {th }}$ phalanxes, and Meta1-Meta5 stands for the $1^{\text {st }}-5^{\text {th }}$ metatarsal bones. Midfoot means middle part of foot, Heel Medial indicates inside of heel, and Heel Lateral means outer side of heel [12]. Figure 1 is the foot pressure test area schematic diagram.

8 sensor measuring points were set up respectively at the thumb, $1^{\text {st }}, 3^{\text {rd }}$ and $5^{\text {th }}$ phalanxes, insides and outsides of instep \& heel [13].

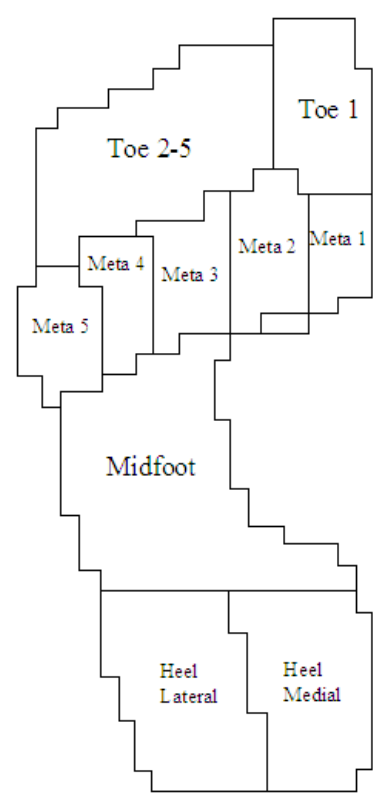

Figure 2. Foot pressure test area schematic diagram 


\section{RESULTS AND DISCUSSIONS}

\section{Gait and Its Phase \& Cycle}

Table 1: The step phase and cycle of the experimental and control groups run test

\begin{tabular}{llllll}
\hline Parameters & $\begin{array}{l}\text { Level } 2(\mathrm{n}=6) \\
\text { Mean } \pm \text { SD }\end{array}$ & $\begin{array}{l}\text { Level } 1(\mathrm{n}=5) \\
\text { Mean } \pm \text { SD }\end{array}$ & $\begin{array}{l}\text { Master }(\mathrm{n}=3) \\
\text { Mean } \pm \text { SD }\end{array}$ & $\begin{array}{l}\text { Average }(\mathrm{n}=14) \\
\text { Mean } \pm \text { SD }\end{array}$ & $\begin{array}{l}\text { Ordinary } \\
\text { Mean } \pm \text { SD }\end{array}$ \\
\hline Pace & $5.5 \pm 0.1$ & $5.44 \pm \pm 0.2$ & $5.49 \pm \pm 0.3$ & $5.4 \pm \pm 0.4$ & $4.46 \pm 0.6$ \\
Step size & $291.5 \pm \pm 7.1$ & $300 \pm \pm 15$ & $324 \pm 22$ & $299 \pm \pm 18$ & $257 \pm 29$ \\
Step time & $582 \pm 8.1$ & $607 \pm \pm 14.5$ & $649 \pm 16.5$ & $595 \pm \pm 14.8$ & $612 \pm 38.8$ \\
Step frequency & $1.72 \pm \pm 0.01$ & $1.65 \pm 0.03$ & $1.54 \pm \pm 0.03$ & $1.67 \pm 0.04$ & $1.50 \pm 0.09$ \\
Support time & $172 \pm 6.5$ & $168 \pm 9.1$ & $167 \pm \pm 12.3$ & $170 \pm \pm 9.3$ & $182 \pm \pm 16.4$ \\
Hang Time & $118 \pm \pm 9.6$ & $134 \pm 19.5$ & $157 \pm \pm 20.9$ & $127 \pm \pm 17$ & $144 \pm 14.5$ \\
Time ratio & $1.45 \pm 0.11$ & $1.25 \pm 0.10$ & $1.07 \pm \pm 0.06$ & $1.33 \pm 0.1$ & $1.25 \pm 0.17$ \\
\hline
\end{tabular}

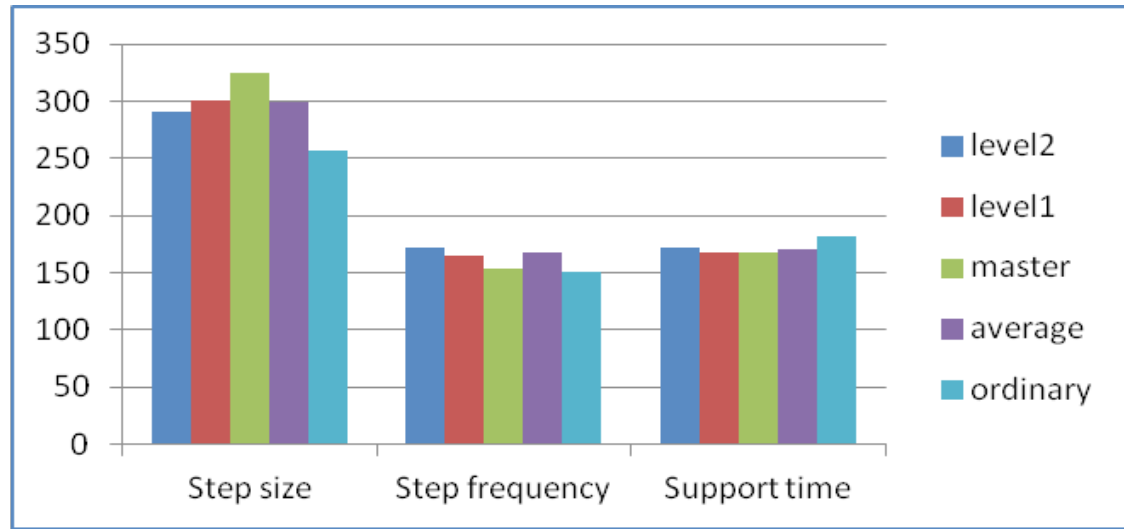

Figure 3. The compare of step size, frequency, support time of each group

According to running posture and its technique cycle, running can be divided into 3 key phases: landing phase, stance phase, and kick-off phase. From data below it can be seen that obvious gap exists in step speed, step size, treading time, support time and step frequency. In addition there's difference of various degrees between different groups within experimental group and between experimental group and control group in terms of step size, step frequency, and support time, which indicates that these 3 are the effective and sensitive indicators to analyze middle-distance running technique.

It can be known from the figure above that stance time of athletes is shorter than that of ordinary teenagers while their step frequency and size are longer than the latter.

\section{Analysis of Foot Pressure in Running}

\section{COP Track of Foot Pressure}

Center of Pressure (COP) is the working point of joint forces in the plantar. It reflects the general distribution of pressure in the plantar. Here we take middle of the back heel as zero point, the line from zero point to head of the $2^{\text {nd }}$ metatarsal phalangeal joint as vertical axis, front as positive direction of the $\mathrm{Y}$-axis, vertical with which the line passing zero point we take as $\mathrm{X}$-axis, and the inside of foot as positive direction of the X-axis [14]. Foot length and width is normalized to reduce impact of foot shape. The point with big inflection is chosen as the start of landing and kick-off. 


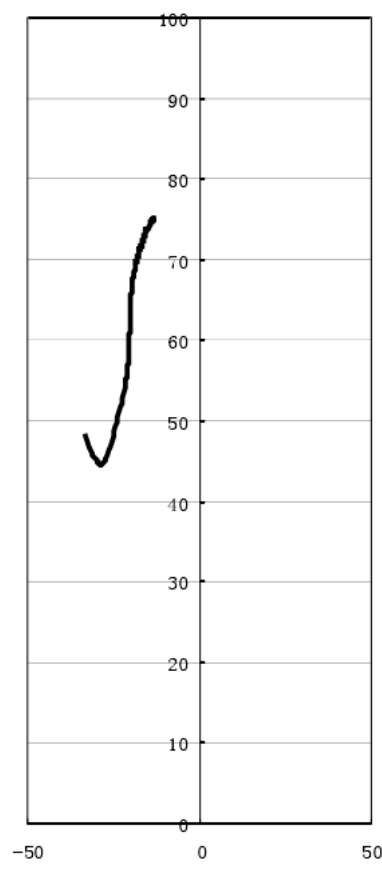

(a) left foot COP track

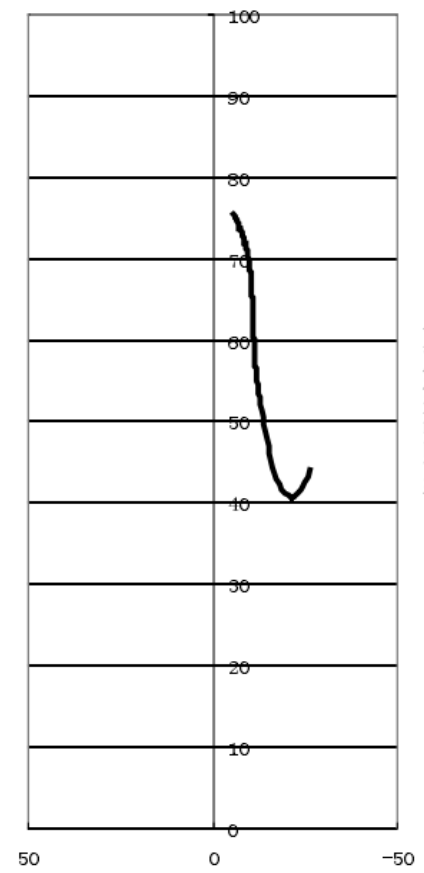

(b) right foot COP track

Figure 4. Athlete's foot pressure center track

In general, left foot COP is more lateral while right foot COP is more medial. The left foot is larger in value than the right foot in both $X$ and $Y$-axis, which shows that the left foot works as the active foot and are more inclined to exert force from the outside while the right foot more tending to land at the heel [15]. At the stance phase the foot COP is at outer side of mid-foot, then moving downward and inward, reaching a pressure peak at the heel and a $2^{\text {nd }}$ peak at the forefoot.

\section{Pressure Integral Distribution of Partitions in the Plantar}

Partitions in the plantar have different functions. The Pressure-Time Integral (impulse) of each reflects its contribution rate to the speed. Figure 5 shows the pressure integral (PTI) distribution of 10 partitions in the plantar.

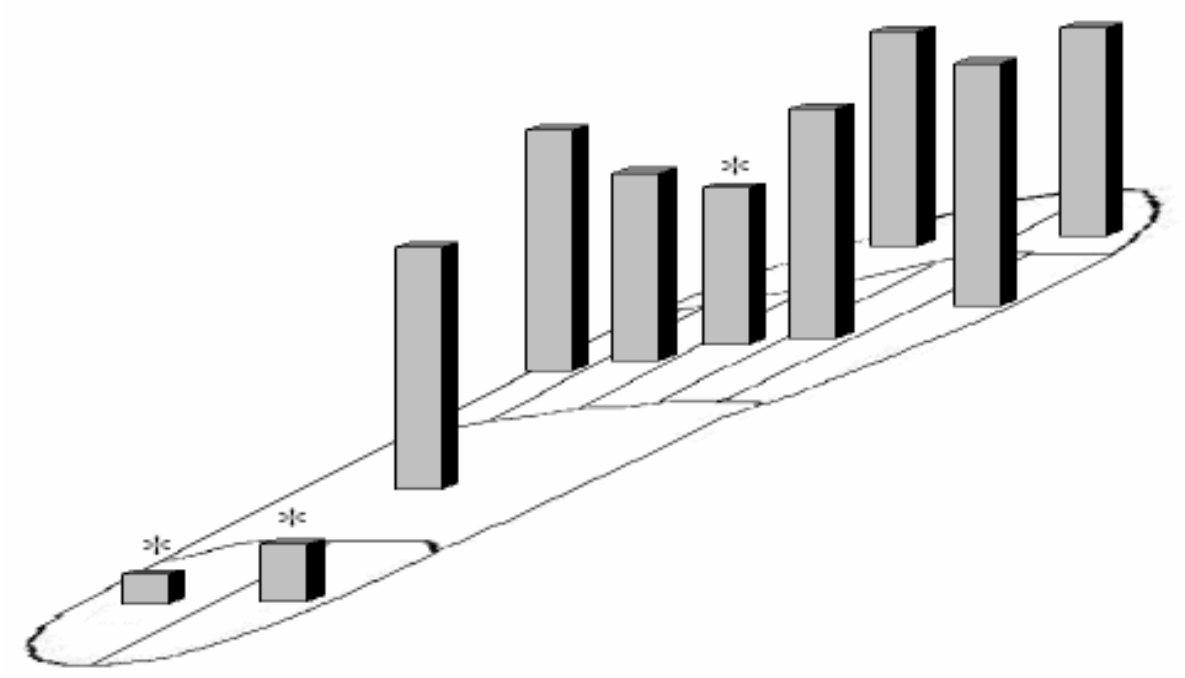

Figure 5. The pressure integral (PTI) distribution of 10 partitions in the plantar 
As shown in the figure, distribution of Pressure-Time Integral is higher at the forefoot and toes, meaning most of the stance is finished at the forefoot in mid-long running. In contrast, contact time between heel and the ground is short, and the pressure between the two is relatively smaller.

Pressure peak is an important index reflecting the pressure distribution in the plantar. Its value is of important impact to foot fatigue accumulate and sport injury [16]. From figure above it can seen that pressure is the highest at M5 and M3 area, where overfatigue may cause arch collapse at the forefoot. Because distribution of pressure peak and impulse is similar in characteristic, forefoot is the main area of load and force drive during mid-long running as the test data shows.

Pressure Peak (PP) Distribution of 8 Points in the Plantar in Mid-Long Running

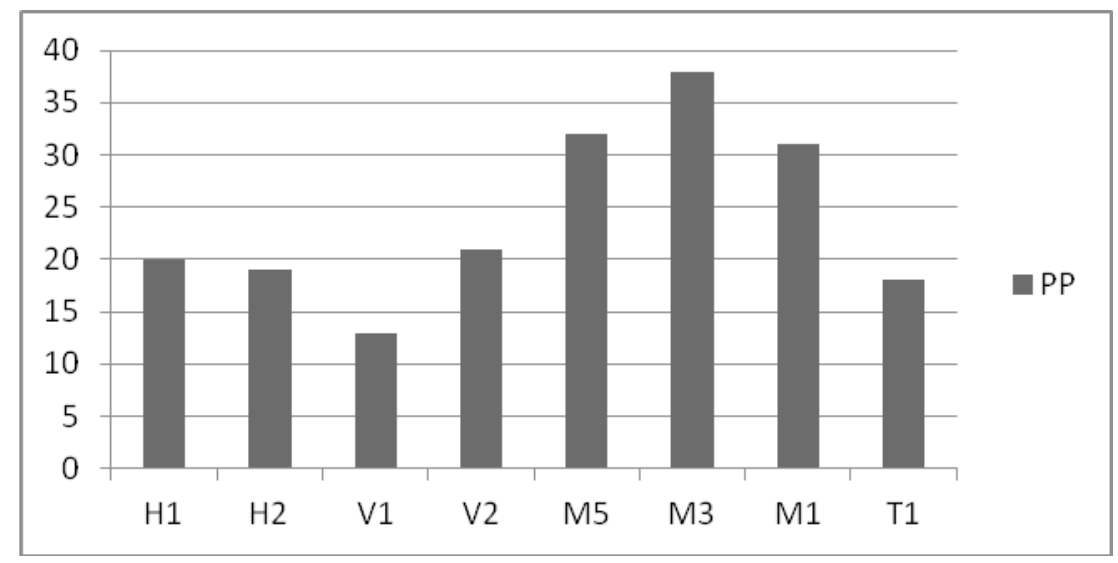

Figure 6. The distribution of pressure peak of plantar in mid-long run

\section{Experiment Result Analysis}

Step Size, Step Frequency, and Step Speed

Step Size is composed of touchdown distance, leg drive distance, support distance during the stance period. From experiment data we can know that the step size decreases successively from master, level 1 to level 2 . In mid-long running step size is in an approximately linear relationship with speed. At specific speed, motor individuals will run with specific step frequency and size while step frequency is independent with the speed.

\section{Distribution of Pressure in the Plantar}

Pressure in the plantar is different in motion from that in rest. During middle-distance running distribution of pressure in the plantar at the forefoot can be divided into 4 categories: medial, mid-medial, central, mid-lateral. It is commonly acknowledged that sportsman should land with foot flat as mid-long running is a kind of endurable sport. However, research of this article has found that some mid-long runners land on forefoot while some others land on arch, with no heel strikers found. For those landing on arch, the landing COP is at mid-lateral foot with larger hitting force peak. For those landing on forefoot, the landing COP is at the $5^{\text {th }}$ metatarsal bone of lateral forefoot with smaller hitting force peak and more flexible change in pressure.

\section{The Relationship between Plantar Pressure and Sport Injury}

Injury of mid-long running is mainly chronic with acute disease rarely seen. However, injury accumulate still deserves attention from athlete. Main reason of injury in middle-distance running includes: 1 . landing at a wrong point of foot; 2 . foot over-pronation; 3 . landing with too big hitting force; 4 . inconsistent stress between left and right foot.

\section{CONCLUSION}

This article uses RS-scan force test system to study characteristics of the foot gait and pressure distribution in mid-long running by selecting 14 mid-long running athletes as well as 8 ordinary teenagers and reaches below conclusion through analysis of test data:

(1) COP track is in a S-shape. Testees land on the outer side of midfoot while kick off at the middle forefoot. As active foot, left foot is different from the right foot because of its more lateral COP track. 
(2) Impulse or PTI in the plantar is more centralized at forefoot, metatarsal bones as well as midfoot and the smallest at the heel. This indicates that the heel contributes the least to the running speed.

(3) Pressure Peak (PP) reaches the highest at the middle of forefoot, meaning this partition suffers the most from impulse load.

(4) Through comparative analysis of test data, during mid-long running forefoot is the main area with risk of sport injury and deserves more attention.

\section{REFERENCES}

1. Lechner, M., Long-run labour market and health effects of individual sports activities, $J$ Health Econ, 2009, 28, 4, 839, https://doi. org/10.1016/j.jhealeco.2009.05.003.

2. Rampinini, E., Alberti, G., Fiorenza, M., Riggio, M., Sassi, R., Borges, T.O., Accuracy of GPS devices for measuring high-intensity running in field-based team sports, Int $J$ Sports Med, 2014, 36, 1, 49-53, https://doi. org/10.1055/s-0034-1385866.

3. Liu, L., Biomechanical analysis on the stop-jump action of patients with knee joint injury, Int $J$ Bioautomation, 2018, 22, 1, 49-56, https://doi. org/10.7546/ijba.2018.22.1.49-56.

4. Woodburn, J., Turner, D.E., Podiatry, biomechanics and the rheumatology foot, Rheumatology, 2010, 171-184, https://doi. org/10.1016/B978-0-443-06934-5.00013-9.

5. Lehmann, M., Dickhuth, H.H., Gendrisch, G., Lazar, W., Thum, M., Kaminski, R. et al., Training-overtraining. A prospective, experimental study with experienced middleand long-distance runners, Int J Sports Med, 1991, 12, 5, 444-452, https://doi. org/10.1055/s-2007-1024711.

6. Wilks, D.C., Winwood, K., Gilliver, S.F., Kwiet, A., Chatfield, M., Michaelis, I. et al., Bone mass and geometry of the tibia and the radius of master sprinters, middle and long distance runners, race-walkers and sedentary control participants: A pQCT study, Bone, 2009, 45, 1, 91-7, https://doi.org/10.1016/j. bone.2009.03.660.

7. Pataky, T.C., Goulermas, J.Y., Crompton, R.H., A comparison of seven methods of within-subjects rigid-body pedobarographic image registration, J Biomech, 2008, 41, 14, 3085, https://doi.org/10.1016/j. jbiomech.2008.08.001.

8. Nunns, M., House, C., Fallowfield, J., Allsopp, A., Dixon, S., Biomechanical characteristics of barefoot footstrike modalities, J Biomech,
2013, 46, 15, 2603, https://doi.org/10.1016/j. jbiomech.2013.08.009.

9. Jr, W.L., Zhang, Y., Adam, B.L., Sutherland, V., Gates, K., Brame, B., A comprehensive study of physical parameters, biomechanical properties, and statistical correlations of iliac crest bone wedges used in spinal fusion surgery. II. Mechanical properties and correlation with physical parameters, Spine, 1994, 19, 3, 296-303, https://doi. org/10.1097/00007632-199402000-00007.

10. Giest, T.N., Chang, Y.H., Biomechanics of the human walk-to-run gait transition in persons with unilateral, transtibial, amputation, J Biomech, 2016, 49, 9, 1757-1764, https://doi. org/10.1016/j.jbiomech.2016.04.004.

11. Bauer, J.A., Cauraugh, J.H., Tillman, M.D., An insole pressure measurement system: repeatability of postural data, Foot Ankle Int, 2000, 21, 3, 221-226, https://doi. org/10.1177/107110070002100307.

12. Pinsault, N., Vuillerme, N., Test-retest reliability of centre of foot pressure measures to assess postural control during unperturbed stance, Med Eng Phys, 2009, 31, 2, 276-286, https://doi.org/10.1016/j. medengphy.2008.08.003.

13. Slim, F.J., van Schie, C.H., Keukenkamp, R., Faber, W.R., Nollet, F., Increased plantar foot pressure in persons affected by leprosy, Gait Posture, 2012, 35, 2, 218-24, https://doi. org/10.1016/j.gaitpost.2011.09.010.

14. Janin, M., Dupui, P., The effects of unilateral medial arch support stimulation on plantar pressure and center of pressure adjustment in young gymnasts, Neurosci Lett, 2009, 461, 3, 245-248, https://doi.org/10.1016/j. neulet.2009.06.043.

15. Zou, D., Mueller, M.J., Lott, D.J., Effect of peak pressure and pressure gradient on subsurface shear stresses in the neuropathic foot, J Biomech, 2007, 40, 4, 883, https://doi. org/10.1016/j.jbiomech.2006.03.005.

16. Actis, R.L., Ventura, L.B., Lott, D.J., Smith, K.E., Commean, P.K., Hastings, M.K., et al., Multiplug insole design to reduce peak plantar pressure on the diabetic foot during walking, Med Biol Eng Comput, 2008, 46, 4, 363-371, https://doi.org/10.1007/s11517-008-0311-5.

(C) 2018 by the author(s). Published by INCDTPICPI, Bucharest, RO. This is an open access article distributed under the terms and conditions of the Creative Commons Attribution license (http://creativecommons.org/licenses/by/4.0/). 